Archived version from NCDOCKS Institutional Repository http://libres.uncg.edu/ir/asu/

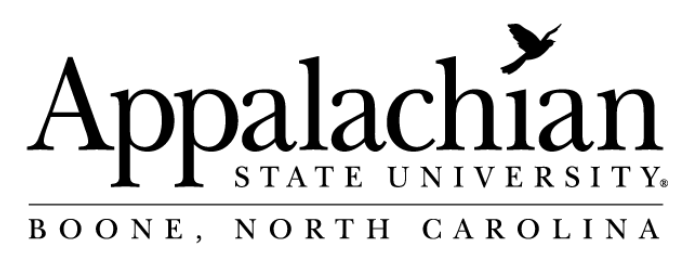

\title{
Crossing the Color Line in Little Rock: The Eisenhower Administration and the Dilemma of Race for U.S. Foreign Policy
}

By: Dr. Cary Fraser

Fraser, Cary. "Crossing the Color Line in Little Rock: The Eisenhower Administration and the Dilemma of Race for U.S. Foreign Policy”. Diplomatic History 24, no.2 (2000). 10.1111/0145-2096.00211 


\title{
Crossing the Color Line in Little Rock:
}

\author{
The Eisenhower Administration and the Dilemma \\ of Race for U.S. Foreign Policy*
}

The Little Rock crisis in 1957 has been accorded major importance in the history of the civil rights struggle in the United States after 1954. ${ }^{.}$The crisis achieved its status as a result of its resurrection of several issues that were germane to the American Civil War and Reconstruction - the conflict between the federal government and a Southern state committed to the subjugation of black Americans; the use of federal armed forces to impose the authority of the federal government in the South; and the decision taken by a Republican president to enforce legal provisions safeguarding the rights of blacks in the face of organized and determined white supremacist opposition led by a Southern governor. It also occurred in the wake of the enactment of the 1957 Civil Rights Act with bipartisan support in the Congress - the first civil rights measure enacted by the federal government since the end of Reconstruction in I877 and one that contributed in considerable measure to the tense political climate in which the Little Rock crisis unfolded. The importance of the Little Rock crisis assumes even greater weight when one considers the fact that

${ }^{*}$ Research for this article was undertaken with the support of a Research and Writing Grant from the John D. and Catherine T. MacArthur Foundation. An earlier version was presented at the Frederick Douglass Institute at the University of Rochester where I benefited from the comments of the late Sam Nolutshungu, Karen Fields, Joseph Inikori, Fred Harris, Tim Parsons, and Henry Kamerling. Nan Woodruff, Emily Rosenberg, David McBride, and Richard Immerman provided useful suggestions at various stages of the revision process. The comments of the anonymous reviewers of Diplomatic History helped me to refine the arguments. Michelle Linnen provided invaluable help by proofreading the paper as I prepared the final draft.

I. The crisis originated in the decision of the governor of Arkansas, Orval Faubus, to prevent the desegregation of the high school in Little Rock in defiance of the orders of federal courts and through the use of the National Guard. For accounts of the crisis see Numan V. Bartley, The Rise of Massive Resistance: Race and Politics in the South during the Igsos (Baton Rouge, 1969); Herbert Brownell, with John P. Burke, Advising Ike: The Memoirs of Attorney General Herbert Brownell (Lawrence, KS, 1993); Robert Frederick Burk, The Eisenhower Administration and Black Civil Rights (Knoxville, 1984); Tony Freyer, The Little Rock Crisis: A Constitutional Interpretation (Westport, CT, 1984); Roy Reed, The Life and Times of an American Prodigal (Fayetteville,1997); and Francis M. Wilhoit, The Politics of Massive Resistance (New York, 1973). For a recent effort to explore the way in which the crisis reflected the interrelationship of American race relations and foreign policy see Mary L. Dudziak, "The Little Rock Crisis and Foreign Affairs: Race, Resistance, and the Image of American Democracy," Southern California Law Review 70, no. 6 (1997): I64I-I716. 
President Dwight D. Eisenhower was profoundly ambivalent about the Supreme Court's decision in 1954 to declare segregation unconstitutional, but was ultimately constrained to use federal forces to apply the law of the land and to assert the authority of the federal government in Little Rock. ${ }^{2}$ Eisenhower's ambivalence in 1957 was not singular. ${ }^{3}$

Although the issues embedded in the Little Rock crisis revealed it to be a chapter of an intrinsically American epic, this paper will explore some other dimensions of the crisis that would suggest that its importance transcended American history even as it ultimately helped to reshape American domestic politics. This study of the Little Rock episode will suggest that the crisis achieved a global significance by provoking a wider debate about the ethic of "white supremacy" that underlay segregation in the United States, apartheid in South Africa, and the colonial order in the non-European world. Further, this essay argues that the Little Rock crisis served as a catalyst for a major shift in the course of American engagement with the world outside of Europe. This is an aspect of the crisis that has hitherto received little attention. Among the consequences of the crisis for the United States was the opening of American domestic politics and race relations to international scrutiny and criticism. As a result, international opinion increasingly became a constituency with which American policymakers had to contend when responding to the challenge of racial reform in the United States. In effect, it is possible to argue that the crisis in Arkansas helps us to rethink assumptions about the relationship between "national" and "international" history and allows students of American history to explore the international sources of change in American society and politics. ${ }^{4}$

2. In a letter to Swede Hazlett, his boyhood friend, Eisenhower confided that "no other single event has so disturbed the domestic scene in many years as did the Supreme Court's decision of 1954 in the school segregation case. That decision and similar ones earlier and later in point of time have interpreted the Constitution in such fashion as to put heavier responsibilities than before on the Federal government in the matter of assuring to each citizen his guaranteed Constitutional rights." For the full text of the letter see Robert Griffith, Ike's Letters to a Friend (Lawrence, KS, 1984), I $83-89$.

3. In his memoirs, Eisenhower indicated that since boyhood "I had accepted without qualification the right to equality before the law of all citizens of this country, whatever their race or color or creed." See Waging Peace, I956-Ig6I (New York, 1965), I48; but at a more visceral level, Eisenhower's views revealed the fear of racial mixing that has informed the American weltanschauung. He confided to Earl Warren that he sympathized with Southerners whose concern "is to see that their sweet little girls are not required to sit in school alongside some big overgrown Negroes." Quoted in Stanley I. Kutler, "Eisenhower, the Judiciary, and Desegregation: Some Reflections," in Eisenhower: A Centenary Assessment, ed. Gunter Bischof and Stephen E. Ambrose (Baton Rouge, 1995), 89.

4. For earlier efforts to explore the linkages that race created between non-European nationalists and African Americans see Rupert Emerson and Martin Kilson, "The American Dilemma in a Changing World: The Rise of Africa and the Negro American," in The Negro American, ed. Talcott Parsons and Kenneth B. Clark (Boston,1966), 626-55; and Mark Solomon, "Black Critics of Colonialism and the Cold War," Cold War Critics: Alternatives to American Foreign Policy in the Truman Years, ed. Thomas G. Paterson (Chicago, 1971), 205-38. For an interesting overview of race as a factor in the international relations of the twentieth century see in its entirety Paul Gordon Lauren, Power and Prejudice: The Politics and Diplomacy of Racial Discrimination (Boulder, 1988). 
As its title suggests, the essay draws upon the observation made at the turn of the century by W. E. B. Du Bois: "The problem of the twentieth century is the problem of the color line, - the relation of the darker to the lighter races of men in Asia and Africa, in America and the islands of the sea." 5 The genius of that insight was Du Bois's recognition that the politics of race in the United States could not be divorced from the fate of non-European societies that had come under the yoke of European and American imperial authority. ${ }^{6}$ The Little Rock crisis was testimony to Du Bois's perspicacity and helps us to understand how the politics of race in the United States was an issue that was simultaneously domestic and international. ${ }^{7}$

The Little Rock crisis was not the first occasion on which there had been untoward foreign policy consequences as a result of the politics of race and segregation in the United States. In the autumn of 1946, several New York hotels had refused to accommodate the UN delegations of Haiti, Liberia, and Ethiopia. As a result, the American Mission to the United Nations had been constrained to intervene to secure accommodation for these delegations and had also sought to prevent this situation from being publicized. ${ }^{8}$ It was evident that the presence of African and other black diplomats, with the privileges associated with diplomatic life, had begun to complicate American domestic politics. As a consequence, the potentially embarrassing consequences of segregation was the sword of Damocles that hung over American pretensions to world leadership after 1945, and the establishment of the headquarters of the United Nations in New York City ensured that the problem would never really leave. While the Secretary-General of the UN and the US Mission to the UN

5. W. E. B. Du Bois, "The Souls of Black Folk," in 3 Negro Classics, intro. by John Hope Franklin (New York, 1965), 221.

6. The intersection of domestic and foreign policy on issues of race has been a consistent theme in the political activism of African Americans. For accounts of the consistency of this theme in African-American history see Gerald Horne, Black and Red: W. E. B. Du Bois and the Afro-American Response to the Cold War (Albany, 1986); Brenda Gayle Plummer, Rising Wind: Black Americans and U.S. Foreign Affairs, 1935-1960 (Chapel Hill, 1996); William R. Scott, The Sons of Sheba's Race: African Americans and the Italo-Ethiopian War, 1935-4I (Bloomington, 1993); Elliot P. Skinner, African Americans and U.S. Policy toward Africa, I850-I924: In Defense of Black Nationality (Washington, 1992); and Penny M. Von Eschen, Race against Empire: Black Americans and Anticolonialism, 1937-1957 (Ithaca, 1997).

7. Several recent studies have pointed to the salience of race for American foreign policy in the non-European world since the Second World War. See Thomas Borstelmann, Apartheid's Reluctant Uncle: The United States and Southern Africa in the Early Cold War (New York, 1993); Cary Fraser, Ambivalent Anti-Colonialism: The United States and the Genesis of West Indian Independence, 1940-64 (Westport, CT, 1994); Richard D. Mahoney, 7FK: Ordeal in Africa (New York, 1983); and, Thomas J. Noer, Cold War and Black Liberation: The United States and White Rule in Africa, 1948-1968 (Columbia, MO, 1985). For a discussion of the influence of foreign policy concerns upon domestic politics and desegregation see Mary L. Dudziak, "Desegregation as a Cold War Imperative," Stanford Law Review 4I (1988): 6I-I20; and the "Symposium: African Americans and U.S. Foreign Relations," Diplomatic History 20 (Fall 1996): 531-650.

8. Thomas F. Power, Jr., memorandum to Samuel Palma, 20 June 1947, Records of the Foreign Service Posts of the Department of State, Record Group 84, United States Mission to the United Nations, 1945-49, box 78, National Archives II, College Park, Maryland. 
were able to intervene to resolve the problem in 1946, the issue remained a festering sore for American diplomacy. ${ }^{9}$

The issue of American race relations, however, was not purely of domestic concern. Despite the relative success in keeping control over the publication of incidents involving foreign dignitaries of color, the State Department had a much more difficult time with a less sympathetic international press and the foreign coverage of racial problems in the United States. In October 1955, the American Embassy in France reported widespread condemnation of the verdict in the Emmett Till case. An all-white jury in Mississippi had acquitted the accused murderers of Till, a teenager from Chicago who had been killed as a result of his decision to solicit the attention of a white woman with whom he was not acquainted. According to the embassy, the French press "gave wide coverage to the Till case, vociferously condemning the verdict. This was true not only of l'Humanite and Liberation, but of the entire press, right wing and left wing alike." Bern reported that the Swiss press had expressed similar views about the decision. ${ }^{\text {II }}$

In early 1956, the American Embassy in Copenhagen reported that the case of Autherine Lucy, a young African-American woman seeking admission into the University of Alabama, was enjoying sympathetic coverage in the Danish press. ${ }^{12}$ The embassy indicated that the administration and students of the two Danish universities (Copenhagen and Aarhus), with support from a local paper, had telegraphed their support and sympathy to Miss Lucy. In addition, the Danish Association for the United Nations and the liberal anti-communist League for Tolerance had decided to send a joint telegram to Miss Lucy expressing their sympathy with "[her] efforts for the observance of human rights and civilization at the University of Alabama." 13 The president of the League for Tolerance and the rector of the University of Copenhagen later telegraphed an offer to register Miss Lucy as a student at the University of Copenhagen and assured her of financial assistance to complete her studies. The American official's report continued with an assessment of the damage being done to American prestige "from such tragedies as the Emmett Till case and the unfortunate riots attending Miss Lucy's efforts." He criticized the American press for contributing to the situation and noted that "intensified efforts of the U.S. press and Government to give a balanced picture in reasonable perspective will of course help." ${ }^{4}$

9. For a discussion of the increasing scale of the problem in Washington after the accession to independence by an increasing number of non-European states see Timothy P. Maga, "Battling the 'Ugly American' at Home: The Special Protocol Service and the New Frontier, 1961-63," Diplomacy and Statecraft 3 , no. I (1992): I26-42.

Io. McBride, despatch to the Department of State, 5 October 1955, General Records of the Department of State, Record Group 59, 8II.4II/I0-555, National Archives II.

II. Freimarck despatch to the Department of State, 30 September 1955, RG 59, 8II. 4II/9-3055.

I2. Allen despatch to the Department of State, 9 February 1956, RG 59, 8II. 4II/2-956.

13. Ibid.

I4. Ibid. He closed his dispatch with the comment that "so long as Southern defiance of the Supreme Court's decision continues and incidents take place, the Danes can be expected to 
Even as the embassy in Copenhagen agonized over the damage done to American "prestige" by the confrontations over segregation, the reaction from the State Department was instructive of the mind-set shaping American foreign policy. Responding to press reports on 8 February of the offer to Miss Lucy from the University of Copenhagen and the Danish League for Tolerance, Secretary of State John Foster Dulles personally contacted the embassy indicating that "information available here identifies League as independent antiCommunist group. Dept regards matter as private non-governmental affair and plans make no comment. President University Alabama informed foregoing." ${ }^{5}$ It was obvious that Dulles saw little need to be concerned about foreign criticism of American race relations. ${ }^{16}$

Despite the administration's sanguine disregard for Danish sentiment, the concerns over American racial problems were not restricted to Europeans. The American consul general in Bombay reported that in the local press there was extensive coverage of American race relations in both the North and the South. The consul general advised that "racial discrimination and racial prejudice as shown in the treatment of Negroes in the United States will probably long continue to be an important adverse factor in the attitude of the Indian people toward the United States." ${ }^{17}$ The American consul in Calcutta reported that press coverage there had also been extensive and critical of developments in the United States. One example of these critical views was an editorial carried by the Hindusthan Standard that pointedly argued that support of white supremacist ideas did little to strengthen American claims to be a champion of democracy. ${ }^{18}$ The Indian coverage of American politics was also influenced by the Montgomery bus boycott and its adoption of Mohandas Gandhi's strategy of passive resistance that had been used to telling effect in bringing an end to the British Raj. One Indian correspondent filing a story from New York for the

continue their avid interest and frequently to misread or exaggerate various incidents to the detriment of U.S. prestige and reputation."

15. Dulles tel. to American Embassy, Copenhagen, 8 February 1956, RG 59, 8II. 4II/2-856.

I6. Eisenhower himself seemed to display very little concern about the actions of state and university authorities in Alabama. In a response to letters from citizens writing Eisenhower about the incident, Maxwell Rabb, the administration's troubleshooter on issues of race, advised that the president had expressed his regret about the incident and his hope that "the State and the University would be able to find a solution." Since 1956 was a presidential election year, it is not impossible that Eisenhower sought to avoid any action that would antagonize Southern white voters and states rights' advocates on the matter of segregation. In the same letter, Rabb expressed the view that "the problem at the University of Alabama is not within the jurisdiction of the federal government and it is indicated that federal intervention in what is essentially a matter of State concern would undoubtedly be interpreted as a violation of the constitutional rights of the individual States." Maxwell M. Rabb to James A. Haljun, 88 February 1956, Papers of Dwight D. Eisenhower, Alphabetical File, box 1894, Eisenhower Library, Abilene, Kansas.

17. Turner despatch to the Department of State, 27 February 1956, RG 59, 8II. 4II/2-2756.

I8. Van Hollen depatch to the Department of State, I3 March I956, RG 59, 8II. 4II/3-I356. The editorial concluded that the "inhumanity of racial arrogance seems to have become the privilege of certain people with blonde skins. The odd thing is that it finds apologists among U.S. leaders who want to convert pigmented Asians to the American cult of democracy." 
Hindu newspaper in Madras, expressed the view that "the bus boycott may well turn out to be an epochal event in the history of the Southern Negro. If it succeeds, it is bound to be copied by other Negroes all over the south where the Whites are fighting a last-ditch battle to preserve segregation of the races." ${ }^{19}$ In hindsight, it would appear that the Indian correspondent's insight into the significance of the Montgomery boycott for the future of American race relations was prescient.

The foreign coverage critical of American race relations was exacerbated by the activities of expatriates like Josephine Baker, the American performer who had built a considerable reputation in Europe as both a performance artist and a political activist. The American embassy in Stocholm reported that Baker had lectured to several audiences in the capital during February and March 1956. On I March she was the featured speaker at a charity benefit organized by the Stockholm branch of the Social Democratic Party where the audience of five thousand people included the prime minister and his wife. The minister of defense introduced Baker, who spoke about developments in the United States and described the current situation as "as bad as it has ever been." ${ }^{\text {2o }}$ Baker's speech provided grist for the ongoing debate among Swedish newspapers about the racial situation in the United States. The embassy reported that Swedish coverage of American race relations was both extensive and critical of the meager record of racial reform. ${ }^{21}$

The reasons for the "unspectacular record of accomplishment" was well illustrated by an internal debate over American policy toward South Africa in 1956. After a trip to Africa in 1956, Mason Sears, who was the American representative on the United Nations Trusteeship Council, forwarded a report on his visit to the State Department. Henry Cabot Lodge, the U.S. representative to the United Nations, sent a letter to Dulles expressing his view that "Mason Sears may have irritated a few hard-shelled colonialists (although he is on good terms with the actual administrators), but he has certainly made a lot of friends for us with the natives, who have the future in front of them and where it means something to the United States for the long pull." ${ }^{\prime 2}$ As would become evident, Sears's report was also to be an irritant to the State Department.

19. K. Balaraman, "Satyagraha' in Alabama Negro Boycott of Buses Walk-to-Work Campaign," in The Hindu, 27 February 1956. A typed copy of this article is attached to Fleck despatch to the Department of State, 28 February 1956, RG 59, 8II.4II/2-2856.

20. Sweeney despatch to the Department of State, 7 March I956, RG 59, 8II. 4II/3-756.

2I. Ibid. According to the embassy, "All of the major Stockholm papers with New York correspondents have published feature articles on the negro problem in the United States in which criticism tends to outweigh the unspectacular record of accomplishment." It was perhaps not surprising that Swedish newspapers should devote considerable coverage to American race relations given the prominent role of Gunnar Myrdal in shaping the American agenda for racial reform after 1945 .

22. The representative at the Trusteeship Council (Sears) memorandum to the secretary of state, 15 February 1956, U.S. Department of State, Foreign Relations of the United States, 1955-1957 (Washington, 1989), I8:30. 
Sears's first recommendation was to suggest that the Fourth of July celebrations hosted by American embassies and consulates in South Africa, Southern Rhodesia, and Kenya should be opened to Africans. He justified his suggestion by arguing that it was unseemly to pander to the racism of white settlers when celebrating American independence. ${ }^{23} \mathrm{He}$ further argued that that the inclusion of Africans at these ceremonies would generate considerable goodwill for the United States in the rest of Africa. Sears was not simply content to make this recommendation and went on to advise that "this is a matter which should not be left to the discretion of our own representatives on the spot. It should come as a clear and specific order from the Secretary of State, especially considering the recent disgraceful race riots in Alabama. It would please many citizens of the United States, and a careful program should be worked out to see to it that American opinion be informed of this decision." 24

The secretary of state, however, was not inclined to agree with the role assigned to him or with the arguments advanced for the policy change recommended by Sears. Lodge again raised the issue with Dulles in late March, and Dulles in his response on 3 April stated his agreement with the principle that invitations should not be discriminatory either at home or abroad, but cautioned that American representatives abroad should be attentive to local conditions. ${ }^{25}$

Despite Dulles's reluctance to endorse Sears's approach, Sears decided to pursue the matter. In June, he visited the State Department in Washington to discuss his recommendation with members of the office dealing with Southern African affairs. There, Sears indicated that the "unencouraging reply" that he had received from the secretary notwithstanding, he still saw merit in the proposal. He reiterated his view that the "inclusion of non-whites at these receptions would have a strikingly beneficial effect upon the attitude of nonWhites throughout Africa towards the U.S. ${ }^{26} \mathrm{He}$ also stated his view that while such a policy shift would antagonize the Afrikaners, it would not have a deleterious effect upon U.S.-South African relations.

As Sears was to discover, his views ran counter to the consensus in the Department of State. The departmental officers with whom he met sought to discourage Sears from further advocacy of his proposal. The desk officers advised Sears that his recommendation would require a complete policy review including consideration of issues of defense and the supply of strategic minerals. They expressed the view that his proposal would poison U.S.-South African relations without "any significant compensatory benefit" and that U.S. policy

23. Ibid.

24. Ibid. (emphasis added).

25. Editorial note, FRUS, I955-I957 18:39. This is a quote from a document cited in the editorial note but the entire document is not provided.

26. Memorandum of conversation between Mr. Mason Sears (U.S. representative and president of the United Nations Trusteeship Council), Donald Dumont (officer in charge, Southern Africa Affairs), and J. J. Durnan, A. J. Davit, W. R. Duggan, and W. M. Johnson (desk officers, Southern Africa Affairs), 7 June 1956, RG 59, 8II.4II/6-756. 
was to support "stability and orderly development in South Africa, including, whenever possible and practicable, the persuasion of responsible South African whites to moderate their restrictive policies." ${ }^{27}$ Sears was informed that the Egyptian charge d'affaires, who was himself dark-skinned, did not invite Africans to Egypt's national day celebrations. Further, the Soviets had been asked to leave South Africa after they had invited non-whites to their national day reception, and the Indian representative had been expelled for "destructive" contacts with non-white leaders. According to the officers, "American officials had gone as far as possible, further than most, in developing contacts with non-whites. .. . By way of example, when Bishop Jordan, an American Negro Bishop of the AME (African Methodist Episcopal) Church, was a visitor to South Africa in 1954, Ambassador E. T. Wailes invited Bishop Jordan and his wife to his residence for tea and included as his guests two South African non-white clergymen who were also members of the AME Church in the Union." ${ }^{28}$ In addition, there was concern that inviting non-whites to the Fourth of July celebrations would lead to a South African government response that would effectively restrict the embassy's ability to maintain contacts with nonwhites. Thus, practicing segregation in South Africa was seen as essential to maintaining good relations with the apartheid regime and providing access to the colored communities of the country. Sears was also informed that South Africa's recent efforts to promote friendly relations with all African territories and willingness to recognize both the Sudan and Ghana suggested that the "Afrikaner was not so inflexible as sometimes labeled." ${ }^{29}$ The presentation by the State Department's officers was so persuasive that Sears called the next day to inform Assistant Secretary of State Francis Wilcox that he was abandoning his proposal and his efforts to see Dulles about the issue..$^{\circ}$

This episode demonstrated the Eisenhower administration's sensitivity to the concerns of the white minority government in South Africa. American sympathy for the South African apartheid regime continued even as apartheid came under increasing criticism in the wider international community. In 1955 , apartheid had been dropped from the agenda of the United Nations after a Costa Rican resolution to have the United Nations General Assembly consider the issue had failed to secure the vote of two-thirds of the members. ${ }^{31}$ The United States had supported the effort to block continued UN consideration and debate of apartheid, though it had carefully sought to avoid playing a leadership role in the negotiations to remove apartheid from the UN agenda.

27. Ibid.

28. Ibid.

29. Ibid.

30. Memorandum of conversation between Sears and Dumont, 8 June 1956, RG 59, 8II. $424 / 6-856$. Sears conceded that his previous proposal would be detrimental to American national interests.

3I. Acting director of the Office of Southern Africa Affairs (Hadsel) to the ambassador in Egypt (Byroade), 3 August 1956, FRUS, 1955-1957 18:786-89. 
One reason for that avoidance of leadership on the issue was the fear that adopting "such a position might place us in an unfavorable light and leave us vulnerable to charges that we were taking the position because of racial conditions" at home..$^{2}$ This awareness of the political liability that South Africa posed for American foreign policy was recognized and articulated very clearly to the ambassador-designate to South Africa in August 1956. He was advised that: "South Africa is one of the West's greatest propaganda liabilities because of its restrictive racial policy directed at all non-whites. The voting on South African issues before the UN can cause the U.S. to be identified with colonialism and the maintenance of apartheid." 33 The sense of shared interests between South Africa and the United States - founded upon their common embrace of white supremacy - was further strengthened by the deepening strategic and economic ties between the two countries. ${ }^{34}$ Segregation, investment, and security formed the tripod upon which "congenial" U.S.-South African relations were mounted.

The Sears démarche had not occasioned any significant departure in the fundamental tenets of American policy toward South Africa. It had, however, sparked a discussion about the domestic ramifications of American policy toward South Africa. Lodge, in his letter of 15 February to Dulles, had expressed concerns about the domestic political repercussions of the segregated celebrations described by Sears. Lodge suggested that the Democrats "would certainly jump on the Fourth of July business if they knew about it. Per contra, we could get some credit at home if we ended this practice." ${ }^{5}$ Lodge's comments may have reflected sensitivities to the fact that 1956 was an election year. With competition for the black vote likely to be part of any electoral campaign, he was undoubtedly seeking to ensure that the Republicans could gain some public

32. Minutes of the Tenth Meeting of the Delegation to the United Nations General Assembly, New York, 25 October 1955, ibid., $775-79$. $786-89$

33. "U.S. Policy toward South Africa," enclosure in Hadsel to Byroade, 3 August 1956, ibid.,

34. Hadsel to Byroade, 3 August 1956, ibid., 786-89. The reasons for the identification of American interests with that of the apartheid regime were clearly articulated to the ambassadordesignate. "From a practical point of view, our relations with South Africa are very friendly and harmonious. South Africa is strongly anti-Communist and pro-West. It looks increasingly to the United States, instead of Britain as formerly, as its model, its leader, and its source of assistance and capital. There is more American capital invested in South Africa today than in any other African territory - over $\$ 300,000,000$. II 6 American companies are represented there, and there are several thousand Americans resident throughout the Union. South Africans of all races are so friendly and hospitable by nature that Americans find life in the Union usually congenial." This harmony was further buttressed by an American assistance program for the extraction of uranium and its reliance upon South Africa for such other strategic minerals as manganese and chrome. In addition, the two countries were working upon a Nuclear Reactor Treaty and improvement of the South African early-warning radar system with help from the U.S. Air Force.

35. A section of Lodge's letter is reprinted as a footnote to Sears's memorandum. is February 1956, FRUS, 1955-1957 18:30. 
relations benefits while denying the Democrats an issue for the presidential campaign.$^{6}$

This Republican sensitivity to the implications of foreign policy for domestic politics was not restricted to Lodge. In February 1955, the New York Times carried an item reporting that the former ambassador to India, Chester Bowles, had expressed his view to Paul Hoffman, a liberal Republican, that the American position in Asia was deteriorating consistently and was losing ground to the Communists. He advocated greater involvement of Democrats in shaping foreign policy to ensure that the Eisenhower administration pursued a genuinely bipartisan foreign policy in order to reverse the situation. ${ }^{37}$ In a letter dated i4 February 1955 to the Times, Bernard Katzen, a consultant to the Republican National Committee, responded to Bowles. He welcomed the proposal for a bipartisan foreign policy and expressed the view that "Mr. Bowles' proposal is not an unmixed blessing as long as the Democratic party is dominated by an element which adheres to a policy of white supremacy." ${ }^{18}$ Katzen added that the memories of Western domination and oppression in Asia were a critical factor spurring the growth of Communist influence. ${ }^{39}$ Citing the dominance of the Southern wing of the Democratic party in Congress, Katzen argued that Democratic participation in shaping American foreign policy would not demonstrate an American commitment to self-determination, the equality of all races, creeds, and colors, or a willingness to deal with the peoples of Asia and Africa "out of respect and not out of sufferance." $4^{\circ}$ The frankness of the debate and Katzen's invocation of the bigotry that permeated Southern political life to stigmatize the Democrats reflected the growing sensitivity to the issue of race in American politics after the Brown decision.

The debate over the appropriate American foreign policy strategy in dealing with Asia was occurring in an international context electrified by the decision of Burma, Ceylon, India, Indonesia, and Pakistan to sponsor a conference of Afro-Asian states at Bandung, Indonesia, in early 1955. As preparations for the conference progressed, the State Department and John Foster Dulles became

36. Lodge, from his position at the United Nations, continued to serve as an adviser to Eisenhower on domestic politics, and this may help to explain in part the administration's increasing sensitivity to the issue of race on both American domestic politics and foreign policy. For a description of Lodge's role see Fred I. Greenstein, The Hidden-Hand Presidency: Eisenhower as Leader (Baltimore, 1994), 60. For an account of the debates within the administration about the strategies needed to win black votes in 1956 see Burk, The Eisenhower Administration and Black Civil Rights, I5I-73.

37. C. L. Sulzberger, "In Search of a Bipartisan Asian Policy," The New York Times, i2 February 1955. Bowles later served as the undersecretary in the Department of State in the Kennedy administration.

38. Letter to the editor, The New York Times, 24 February 1955.

39. Ibid. According to Katzen, "It is these memories of past grievances and wounded pride, because of the color line, which are mainly responsible for the aloofness of the peoples of Asia and Africa to the Western democracies."

40. Ibid. 
increasingly aware of the unsettling implications of the conference for Western pre-eminence in the international system..$^{4}$ The situation was made worse by the decision of Harlem Congressman Adam Clayton Powell, Jr., to attend the Bandung Conference despite opposition from the Eisenhower administration. At the meeting itself, it was left to Powell to defend the American record on race relations and endorse the strategy of gradual racial reform that had begun..$^{22}$ Powell's presence at Bandung, and the predicament it represented for the Eisenhower administration, symbolized the complications that race in American domestic policy posed for the administration's efforts to position the United States as a world leader. Bandung and Powell represented the assertiveness of people of color both inside and outside of the United States and the growing challenge to white supremacy in both international and domestic terms. Inevitably, the actions of the world of color outside of the United States had implications for American domestic politics, a reality underscored by the conference at Bandung.

This sensitivity to non-European views of the direction of American foreign policy had been displayed by John Foster Dulles as early as $1953 .{ }^{43}$ The concern among people of the Third World about the American agenda was addressed in an even more direct fashion by Vice President Nixon. The latter had made a tour of several African countries in early 1957 and had attended the independence celebrations of Ghana during that tour. In his report to President Eisenhower, submitted before the Little Rock crisis, Nixon wrote: "We cannot

4I. The American response to the Bandung Conference has been explored in Cary Fraser, "Grappling with the Specter of Neutralism: The United States and the Bandung Conference" (Paper presented at the 1997 Meeting of the Society for Historians of American Foreign Relations held at Georgetown University, 19-22 June 1997). Dulles was particularly forthright about his opposition to the implications of the Bandung Conference in a meeting at the Department of State in January 1955: "The Secretary said that, if the nations invited to Bandung, acquired the habit of meeting from time to time without Western participation, India and China because of their vast populations will certainly dominate the scene and one by-product will be a very solid block of anti-Western votes in the United Nations." Memorandum of conversation, Subject: Afro-Asian Conference, Secretary's Office, 7 January 1955, I4 January 1955, RG 59, 670.90I/I-I 455 .

42. For accounts of Powell's trip see Charles V. Hamilton, Adam Clayton Powell, Fr: The Political Biography of an American Dilemma (New York,1991), 237-48; Wil Haygood, King of the Cats: The Life and Times of Adam Clayton Powell, Fr. (New York, 1993), 199-204; Plummer, Rising Wind, 250-53; and Adam Clayton Powell, Jr., Adam by Adam: The Autobiography of Adam Clayton Powell, Fr. (New York, 1971), I02-20. In his autobiography, Powell remembered his trip to Bandung as a transformative experience that led him to become more militant in his espousal of the civil rights agenda within the United States. At the time, he was castigated by many in the black community while endearing himself to influential whites and the Eisenhower administration.

43. Radio address by the Honorable John Foster Dulles, secretary of state, on his recent trip to the Near East and South Asia, I June 1953, FO 371/103515, Public Record Office, Kew, United Kingdom. In his address, Dulles commented on the fact that "most of the peoples of the Near East and South Asia are deeply concerned about political independence for themselves and others. They are suspicious of the colonial powers. The United States too is suspect because, it is reasoned, our NATO alliance with France and Britain requires us to try to preserve or restore the old colonial interests of our allies." 
talk equality to the peoples of Africa and Asia and practice inequality in the United States. In the national interest, as well as for the moral issues involved, we must support the necessary steps which will assure orderly progress towards the elimination of discrimination in the United States." 44 Thus, for Nixon, Dulles, Lodge, and other American policymakers, it was evident that the legal architecture of segregation and its implication of white supremacy in the United States were significant impediments to the credibility of the United States as it sought to extend its influence into the non-European world.

The State Department's willingness to defend South Africa did not imply that the American government was hostile to the idea that a transition from colonial rule was imminent by the mid-1950s. One of the early strategies suggested for dealing with the changing African situation was for the United States to adopt a policy "supporting a multi-racial approach to the problems of Africa South of the Sahara. Any other course of action would, in the long run, meet with such domestic opposition within the United States that it would be next to impossible to carry out." 45 American support for multiracialism in Africa was born of the declining legitimacy of white supremacist ideology in American domestic politics. At one level, it was a reflection of the sustained interest of African-American activists in African issues. ${ }^{46}$ At another level, support for aid to Africa could reconcile both domestic and foreign policy imperatives - aid could be used as a mechanism for extending American influence in Africa and accommodating African-American sentiment on an issue of great sensitivity. ${ }^{47}$

In the years leading up to the Little Rock crisis, American segregationist practices and assumptions of white supremacy had come under question from both its allies and enemies in Europe and from the increasingly assertive non-European world. The foreign criticism stimulated the growing recognition of the fact that American domestic politics had become a foreign policy issue

44. Richard Nixon, "The Emergence of Africa: Report to President Eisenhower by VicePresident Nixon," Department of State Bulletin 36 (22 April 1957): 635-40 (emphasis added).

45. Assistant secretary of state for Near Eastern, South Asian, and African affairs (Allen) memorandum to the secretary of state, i2 August 1955, FRUS, 1955-1957 18:20.

46. For accounts of African-American efforts to influence American policy toward Africa see Plummer, Rising Wind; and Von Eschen, Race against Colonialism.

47. This sense of the increasing importance of Africa to American politics and foreign policy was evidenced in a State Department memorandum in December 1955. Arguing the case for the extension of American technical assistance to European colonies in Africa and the Caribbean, the memorandum suggested that "If we do not gradually ease into the picture there, a rising nationalistic sentiment among the peoples south of the Sahara will look elsewhere for help and sympathy. It is a most fertile field for future (and not so distant future) Soviet activity. Moreover, American Negroes are beginning to look on Africa south of the Sahara with somewhat the same kind of sympathy and interest as American Zionists look on Israel. We should capitalize on this sentiment, utilizing it to work towards evolution rather than revolution in Africa. American Negroes, who are our best hope of keeping Africa oriented towards the United States, are anxious for the Department to help in the improvement of economic conditions in Africa and would be very much upset by a decision against any technical assistance programs there." See assistant secretary of state for Near Eastern, South Asian, and African affairs (Allen) memorandum to the secretary of state, 28 December 1955, FRUS, 1955-1957 18:23. 
in an era of increasing American involvement with, and attempts to influence, the international system. Moreover, the growing sensitivity to issues of race promoted a reconsideration of the importance of Africa to American politics and the views of African Americans in devising American foreign policy. In addition, the Suez crisis of 1956 had revealed the widening rift between the Eisenhower administration and its European allies over the style and objectives of Western engagement with the non-European world. It was perhaps inevitable that, after the humiliation of Suez, European sentiment would tend to be unsympathetic to the Eisenhower administration's hubris on race. Having cast itself as more enlightened than its European partners on the issue of colonialism in dealing with Suez, the United States found itself challenged to display its progressive sentiment on race in its domestic politics. Little Rock had become the Suez of the Eisenhower administration - a moment of crisis that forced a fundamental and radical reassessment of existing approaches to dealing with the world of color. And like the European colonial powers after Suez, it would require several years and changes in existing leadership - the accession to office by Harold Macmillan in Britain, Charles de Gaulle in France, and John F. Kennedy and Lyndon B. Johnson in the United States - for the required changes to be implemented in the various countries.

Eisenhower sent troops to deal with the crisis in Little Rock with the full recognition that he needed to reassert the authority of the federal government against a challenge from a Southern governor who had insisted upon defying the authority of the federal courts on the volatile issue of desegregation. The decision to send troops into the South came barely two months after the president had publicly stated that he could not envisage the need to use troops to enforce the orders of federal courts. ${ }^{48}$ For Eisenhower, given his desire to court Southern whites as a key constituency in the 1952 and 1956 presidential elections and his own sympathy for their sensitivities on the issue of ending segregation, it was undoubtedly a wrenching decision. It was also probable that one of the reasons for his vacillation in his dealings with Governor Orval Faubus in Arkansas may have been the fear that sending military forces into the South, as the Republicans had done during Reconstruction, would cost his party dearly in the 1960 election. 49

48. Burk, The Eisenhower Administration and Black Civil Rights, 173.

49. One of the interesting aspects of the workings of the Eisenhower White House was the care lavished upon ensuring that the administration did not appear to be solicitous of AfricanAmerican concerns. One perspective was provided by E. Frederic Morrow, the first black presidential assistant. As the racial tensions in the country mounted and the Little Rock crisis unfolded, Morrow lamented, "I have been powerless to do anything. The President's advisers have not asked me my thinking on these matters, and I am too well-schooled in protocol to advance any uninvited ideas." E. Frederic Morrow, Black Man in the White House (New York, 1963), 122-24. Robert Burk was of the view that the White House was more interested in having black government employees "as symbols of national racial democracy rather than in their usefulness as policy makers." As a consequence, the resident troubleshooter on racial matters was Maxwell Rabb, a former volunteer assistant to Henry Cabot Lodge who was Jewish and "liberal." See Burk, The Eisenhower Administration and Black Civil Rights, 70. 


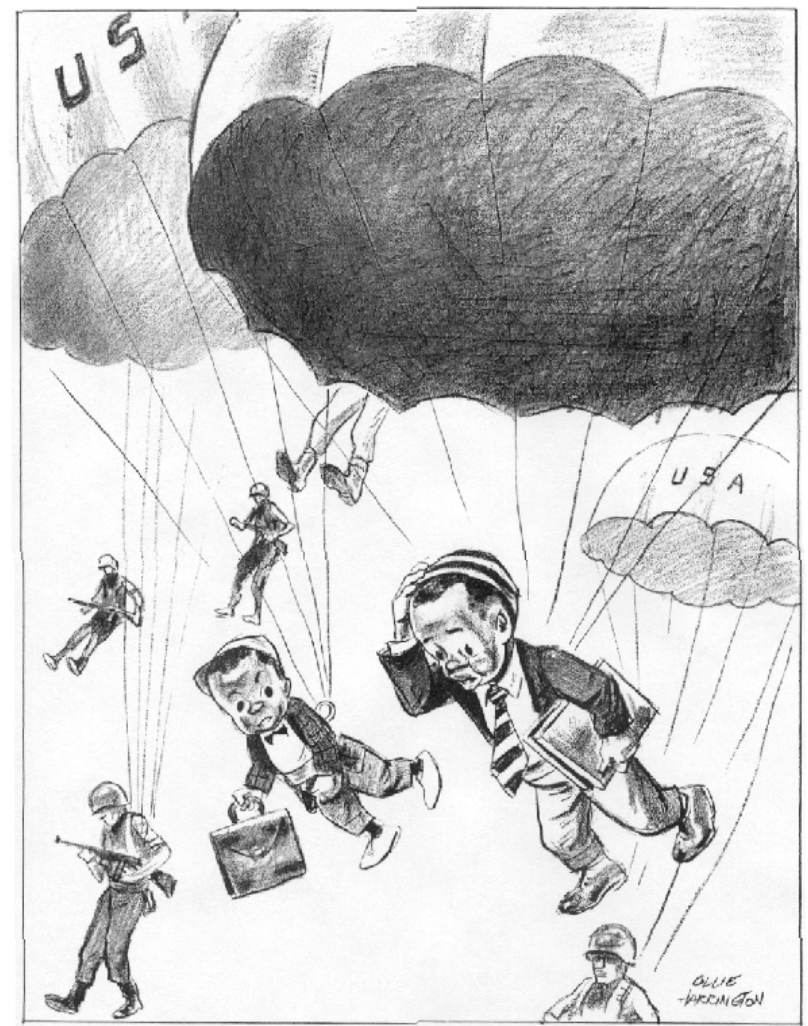

"No, I ain't scared, but you gotta admit, this is a hell of a way to get a education!"

Cartoon by Ollie Harrington. Permission: The BALTIMORE AFRO-AMERICAN NEWSPAPER.

In spite of his own personal and political inclinations, Eisenhower's decision reflected the success of such advisers as Attorney General Herbert Brownell and Secretary of State John Foster Dulles in persuading the president that the Little Rock crisis was a defining moment. According to Brownell, the administration had been preparing for a crisis on the scale of the one that developed in Little Rock. Thus, contingency planning had focused upon establishing the legal framework for presidential intervention in a crisis.

Dulles, for his part, had indicated in early September that the pictures of the confrontation in Little Rock had not been helpful to American foreign policy.50 Just hours before Eisenhower addressed the nation on radio and television about his decision to send troops, Dulles and Brownell discussed the

50. Department of State Press Release, no. 507, Io September 1957, John Foster Dulles Papers, box II9, Seeley Mudd Library, Princeton University, Princeton, New Jersey. 
crisis. Dulles reiterated his view that "this situation is ruining our foreign policy. The effect of this in Asia and Africa will be worse for us than Hungary was for the Russians." ${ }^{51}$ Brownell informed Dulles that Eisenhower had been given "the USIA report which mentioned the use Nasser and Khruschev were making of it. The President was very alert to this aspect." ${ }_{52}$ The international reaction to the crisis had become a factor weighing upon the administration's strategy for dealing with the crisis. Eisenhower's address explicitly recognized the international reaction: "it would be difficult to exaggerate the harm that is being done to the prestige and influence, and indeed to the safety, of our nation and the world." ${ }_{33}$ The address was translated into forty-three languages and the details of the deployments were broadcast over the Voice of America. Eisenhower was acting to reassure foreign audiences that his administration was committed to enforcing the authority of the federal government, including the use of troops, to protect the rights of African Americans.

The increasing international attention to the desegregation struggle in the United States was not prompted solely by the international prominence of the United States and its conflict with the Soviet Union. The inherent advantages of a well-developed system for disseminating news internationally also contributed, as did European resentment of American behavior during the Suez crisis. Just as important was the fact that the developments in the United States awakened anxieties among the European states that were confronted by analogous problems in their colonies or in their own societies. The criticism of the United States that emerged often reflected the awareness that few Europeans or their descendants outside of Europe were able to cast the proverbial first stone on the issue of the treatment of minorities within Europe or people of color in the world outside of Europe. They were aware that the resolution of the problem of segregation in the United States would have enormous implications for their own ability to deal with the color line in their own societies or empires. Nazi Germany had demonstrated the ultimate logic of the ideology

5I. Memorandum of a telephone conversation between the secretary of state and the attorney general (Brownell), Washington, 24 September 1957, FRUS, 1955-1957 (Washington, 1987), 9:612-I3. In an earlier conversation on the same day with Senator William Knowland, the influential Republican from California, Dulles indicated that the situation made "him sick at heart" after Knowland had expressed the view that "if we can't counteract the Little Rock thing we will undo all the good will we have build [sic] up in the world." Memorandum of telephone conversation, 24 September 1957, Papers of John Foster Dulles, Telephone Calls Series, box 7, Eisenhower Library.

52. Memorandum of a telephone conversation between the secretary of state and the attorney general (Brownell), Washington, 24 September 1957, FRUS, 1955-1957 9:612-13.

53. Radio and television address to the American people on the situation in Little Rock, 24 September 1957, Public Papers of the Presidents of the United States, Dwight D. Eisenhower, I957 (Washington,1958), 689-94. In a letter to Senator Francis Case of South Dakota, Eisenhower thanked him for his approval of Eisenhower's address and continued "unfortunately, a handful of irresponsible citizens have managed to defame the image of America before all the world." Eisenhower to Francis Case, 30 September 1957, Eisenhower Papers, Central Files, OF I42-A-5, box 732 . 
of racial supremacy.54 The experience of the United States, which held the largest minority of color among the Western states, and its leadership role within the Western alliance had become a touchstone of the relationship between the white and colored worlds.

From Brussels, the American embassy reported that the press coverage of the racial situation in the United States betrayed resentment "of so-called American 'anti-colonialism' [and questioned] whether America's handling of its racial problem qualifies it to champion allegedly oppressed peoples living under colonial rule." 55 The dispatch indicated that the Belgian response reflected concern about the situation in the Belgian Congo, where the record of the white colonists on race relations left a lot to be desired. Similarly, the embassy in Paris attributed the heightened emotional reaction to the verdict in the Emmett Till murder case to "the unfortunate timing of the event. The trial broke at a time when French sensitivities were aroused over foreign criticism of the French handling of the North African situation. [The acquittals] gave the French an opportunity, which was eagerly seized, to point to racial problems in the United States and to indulge in an outraged sense of indignation and innocence." ${ }^{16}$ The embassy in Auckland reported that concern about the parallels that could be drawn between the treatment of the Maori in New Zealand and blacks in the United Sates seemed to have motivated some of the harsh criticism directed at the United States. ${ }^{57}$

Yet reaction to the American racial situation was not relatively uniform across all of the European imperial states. The American consul in Oporto reported that a commentator for one of the local newspapers, in his commentary on race relations in the United States, was much more sanguine about the history of Portuguese race relations. According to an editorial in Fornal de Noticias, "Fortunately, in our country racial prejudice does not exist; it is repudiated by our people, which in my opinion is one of the marks of the superiority of their character and intelligence." 58 Thus, for some the racial situation in the United States was a comforting reassurance of their own

54. The USIA reported from Bonn that while the Little Rock crisis had received extensive press coverage in Germany, there had been considerable restraint in commentary on the issue. The lack of criticism was attributed to "German awareness [of their] own vulnerability on [the] question [of] persecution racial minority." Bruce tel. to USIA, 5 October 1957, RG 59, 8II.4II/I0-557.

55. Alger despatch to the Department of State, 20 March 1956, RG 59, 8II. 4II/3-2056.

56. McBride despatch to the Department of State, 5 October 1955, RG 59, 8II.4II/IO-555.

57. Fraleigh despatch to the Department of State, I3 March I956, RG 59, 8II.4II/3-1356.

58. The editorial continued: "In our universities no anti-racial measures have ever been considered. On the contrary, the colored man is treated with special affection. The negro among us enjoys popularity, as witness that of certain soccer players. Likewise in Brazil, where despite the large percentage of colored citizens, racial prejudice is nonexistent. On the contrary, the Brazilian is fully aware of the importance of the negro contribution to his civilization - the docility, simplicity and resigned courage in the face of the worse hardships, the obstinate sensuality - as pointed out by a favorite poet." Reed despatch to the Department of State, I4 March 1956, RG 59, $8 \mathrm{II} .4 \mathrm{II} / 3-\mathrm{I} 456$. 
exceptional enlightenment on the issues of race and their own imperial strategies. The lack of irony in the statement suggested the capacity for selfdeception by the imperial powers - even those representative of the European fascist impulse of the igzos.

Nonetheless, the Little Rock crisis, involving as it did the direct challenge to the authority of the federal government and the use of troops to resolve the confrontation, magnified both the stakes and the level of concern. The embassy in Brussels reported that Little Rock and segregation was receiving more press coverage than any previous American domestic issue. In addition to criticisms of American racial bigotry and the questioning of "the high moral attitude adopted by the United States in international affairs ... many newspapers now seem to be much more concerned about the effects of Little Rock on American prestige in Asia and Africa than in Belgium." ${ }^{9}$ These concerns were echoed in Berne where the embassy reported that the "general reaction is one of sober dismay over display of such violence and resulting incalculable harm done to [the] occidental position throughout the non-European world." The Swiss concern also extended to the fact that Little Rock had occurred at the same time that the United Nations General Assembly was debating the Soviet-led invasion of Hungary in 1956 and its aftermath. ${ }^{6}$ In effect, European commentary acknowledged that American foreign policy had been compromised by the crisis in Little Rock. In Luxembourg, the reaction was very similar to that of the Swiss. The Socialist Tageblatt editorialized that "Little Rock was a happy find for the Communists as a means of overshadowing the condemnation of the Hungarian massacre and the new Anti-Semitism in the Soviet Union." ${ }^{61}$ From Amsterdam, the embassy reported that the Little Rock crisis was seen as "unbecoming of a nation which continually affirms its devotion to principles of liberty, equality, and equal opportunity for all citizens." In addition, there was the fear that the entire episode would undermine America's moral authority in the world of color. ${ }^{62}$

The fear of the damage done by the Little Rock episode was generally assuaged by the decision to send troops to enforce the orders of the federal courts. In Belgium, the "despatch of federal troops was warmly applauded and interpreted as a clear demonstration of American determination to enforce the law." ${ }^{3}$ In Amsterdam, one newspaper saw the president's decision to send the troops to Little Rock as analogous to the decision to send troops to Europe during the Second World War - it was a commitment to the protection of human rights. ${ }^{6}$ According to the Luxembourg Tageblatt, Eisenhower's decision

59. Vance despatch to the Department of State, 8 October 1957 , RG 59, 8II. 4II/I0-857.

60. Taylor despatch to the Department of State, I2 September 1957, RG 59, 8II. 4II/9-I257.

6I. Christensen despatch to the Department of State, 30 September I957, RG 59, 8II. 4II/9-3057.

62. Chalker despatch to the Department of State, i6 September I957, RG 59, 8II. 4II/9-I657.

63. Vance despatch to the Department of State, 8 October I957, RG 59, 8II. 4II/I0-857.

64. Young tel. to the Secretary of State, 26 September 1957, RG 59, 8II. 4II/9-2657. 
to send troops "saves not only a principle but the soul of a country which, if it had permitted the situation in Little Rock to continue, could no longer have laid claim to being the leader of the free bloc." ${ }_{5}$

The response in Africa provided a very revealing insight into the current state of opinion in the European colonial possessions. In Nigeria, the West African Pilot raised the question: "What moral right have Americans to condemn apartheid in South Africa when still maintaining it by law?" and concluded that Little Rock "has shown that the US has no moral claim to be leader of Western democracies; that one can't be world champion of the colonial peoples while championing inequality in one's backyard." ${ }^{66}$ Vice President Nixon had certainly captured African sentiment in his report to the president. In Dakar, the American consul general reported that the French and African reactions to Little Rock differed substantially. The French reaction, he reported, was a sense of self-congratulation and moral superiority since "we do things better here and in France." He reported that many of his French friends, who in previous months had been complaining about sending their children to schools with African pupils, "suddenly, became rather proud of the fact. Numerous French officials hinted, always politely, that perhaps Little Rock would make the United States a little more sympathetic to France's problem in Algeria, and especially at the coming U.N. Session." ${ }^{67}$ The local population, however, was apparently impressed with Eisenhower's firm stance during the crisis, and the use of troops was seen as a reflection of the president's resolve. ${ }^{68}$ As a consequence the consul general saw the president's handling of the matter as having substantially improved the American image in Africa.

In South Africa, there was a similar development where sentiment differed among whites and blacks. The consul general in Johannesburg reported that blacks were generally shocked by the incident but had grown to appreciate that the events triggering the crisis were "counter to general public opinion in the United States and to U.S. national policy." On the other hand, the whites seemed to feel that their own apartheid policies had been vindicated by the crisis in Little Rock. ${ }^{69}$ In Mozambique, the consulate reported that Little Rock had become a symbol of black-white relations in the United States and that

65. Christensen despatch to the Department of State, 30 September 1957, RG 59, 8II. 4II/9-3057.

66. Hunt despatch to the Department of State, I4 October 1957, RG 59, 8II. 4II/IO-I457.

67. Mallory-Browne despatch to the Department of State, 30 October 1957, RG 59, 8II. $4 \mathrm{II} / \mathrm{I0}-3057$.

68. Ibid. The consul general went on to report that the Little Rock crisis had been widely discussed and had become known to villages deep in the interior. He reported the view of a leading Senegalese politician that the president's action in dispatching troops to Little Rock had had an enormous impact upon Africans: "M. Doudou Gueye said that at Bamako, where several thousand Africans were gathered from all parts of the area, Little Rock was a topic of intense discussion, and the consensus had been that the President would not dare use federal troops to enforce de-segregation. When he did so, Africans were deeply impressed."

69. Beach despatch to the Department of State, 5 December 1957, RG 59, 8II. 4II/I2-557. 
American "moral standing has been considerably damaged and in [the] Portuguese view here any pretension of an American to advise any European Government on African affairs at this point would be hypocrisy." ${ }^{\circ}$

In Indonesia, the pro-government newspaper Sulub Indonesia published an open letter to the American ambassador and the American community in Jakarta that was remarkable for its spirited criticism of the events in Little Rock. The newspaper pointed to the contradiction of Americans championing democracy abroad even as domestic race relations raised serious questions about the American commitment to democracy at home. The newspaper further suggested that the citizens of Arkansas and other Southern states should pay a visit to Indonesia to learn about tolerance. ${ }^{7}$

On a much more practical level, the Little Rock situation was also problematic for American diplomacy at the United Nations. Henry Cabot Lodge, after applauding the president for his decision to send troops, reported that "at the United Nations I can see clearly the harm that the riots in Little Rock are doing to our foreign relations. More than two-thirds of the world is non-white and the reactions of the representatives of these people is easy to see. I suspect that we lost several votes on the Chinese communist item because of Little Rock." ${ }^{2}$ On the positive side, Lodge reported that Indian prime minister Jawaharlal Nehru, during the course of a visit to Japan, had praised Eisenhower's actions in sending troops to Little Rock. Lodge opined, "That goes a long way."

Thus, the Little Rock crisis opened a window through which the international politics of race became inextricably linked with American domestic politics. The gap between the American championship of democracy abroad and the reality of violent resistance to racial and political equality at home had been laid bare for the entire world to examine and pass judgment. In the wake of the Little Rock crisis, the United States discovered that it needed to devise a solution to the issues of racial inequality and the politics of exclusion at home in a way that would make its championship of democracy and anti-colonialism abroad a credible foreign policy. The decision to use the troops in Little Rock had clearly signaled a level of commitment by the federal government to the idea of desegregation. In a sense, American efforts to assert a leadership role in the non-European world had become hinged to the idea that its domestic race relations would be an index of its "fitness" to claim such leadership. It was a context that would fuel the ongoing struggle for equality in the United States and the rise of a civil rights movement that was aware of the capacity of international scrutiny to influence the course of American politics.

70. Simpson despatch to the Department of State, 30 September 1957, RG 59, 8II. 4II/9-3057.

7I. Bell despatch to the Department of State, 7 October 1957, RG 59, 8II. 4II/Io-757.

72. Lodge to the president, 25 September 1957 , Eisenhower Papers, Ann Whitman File, Administration, Folder - H. C. Lodge, 1957-58.

73. Lodge to the president, I6 October 1957, Eisenhower Papers, Ann Whitman File, Administration, Folder - H. C. Lodge, $1957-58$. 
One of the immediate consequences of the Little Rock crisis for American foreign policy was the preparation within the State Department of a paper on "Talking Points to Overcome Adverse Reaction to Little Rock Incident." The information compiled was then circulated to all field missions and the United States Mission at the United Nations for their guidance. ${ }^{74}$ In a cover instruction from the Department of State to the chiefs of mission or principal officers, Acting Secretary Christian Herter stated "The Department realizes further that remedial action will be a long range operation and that the damage that has been done the United States by sensational newspaper accounts and photographs cannot be repaired overnight." He asked recipients to give serious thought to the steps needed "to start the long and slow job of putting these unfortunate incidents in their proper perspective." 75 As the document made clear, the State Department was concerned to ensure that international views of Little Rock should be seen as an aberrant episode in the ongoing process of racial reform. It emphasized that in the majority of American states, the process of school desegregation was not as contentious as the Little Rock crisis may have suggested. It also argued that the increasing employment of blacks in the federal government, the desegregation of the military, and the growth in home ownership and rising income levels among non-whites in the United States all indicated the quiet improvement in the lives of black Americans. The document then went on to explain that the problems arising from its efforts to lower discriminatory barriers were not singular to the United States, and that the commitment to freedom and equality for individuals had been affirmed by the crisis itself. The final paragraph was a revealing glimpse into the concerns of the authors of the document: "In the United States, national authority is being used not to suppress individual equality and freedom but to uphold them. In the Little Rock incident national authority has been invoked to maintain [the] equal rights of a minority. In the Soviet Union national authority has been repeatedly invoked to suppress the rights of minorities." ${ }^{6}$ It was evident that there was a perceived need to avoid any parallels being drawn between the policies of the Soviet Union and those pursued by the United States.

The Eisenhower administration had become increasingly concerned about the exploitation of its domestic racial problems by the Communist states. In the wake of the Little Rock crisis, Eisenhower asked Henry Cabot Lodge for

74. Berding memorandum to Rubottom, I October I957, RG 59, 8II. 4II/IO-I59.

75. Herter, Department of State instruction to Missions in Sub-Saharan Africa, Io October 1957, RG 59, 811.4II/10-1057.

76. Berding memorandum to Rubottom, I October 1957, RG 59, 8II.4II/IO-I59. This was not the only initiative by the Eisenhower administration to provide its perspective on the situation of black Americans in the contemporary United States. In November 1957, Secretary of Labor James Mitchell sent Dulles a copy of his article "The Negro Moves Up," which was due for publication in the December issue of the Reader's Digest. Mitchell to Dulles, I3 November 1957, Dulles Papers, box II9, Mudd Library. Dulles responded that "This comprehensive report with its impressive background of statistical facts should clear up a lot of misunderstanding overseas." Dulles to Mitchell, 20 November 1957, Dulles Papers, box II9, Mudd Library. 
"suggestions to repair the damage done to our world position by the events at Little Rock." 77 Lodge suggested that U.S. diplomatic representatives should make a sustained effort to offer hospitality to distinguished colored people across the board and not only in the non-European world. Further, he recommended that the United States extend a loan to India, given India's importance among the new nations in the international system. He also reiterated his position that the United States should support a major UN program for multilateral economic aid to the Third World and welcomed recent signs that the State Department was coming to support such a program. He indicated that "The prestige which the Soviet Union is getting because of its satellites intensifies the importance of effective non-communist technical and economic assistance coming in a way which does not look like the US-USSR power struggle. ${ }^{18}$ Thus, Little Rock had become a catalyst for the reassessment by the administration of its terms of engagement with the Third World and the increasing competition with the Communist powers for influence in the nonEuropean world.

This concern with the implications of American race relations for American relations in the non-European world was of immediate concern during the Little Rock crisis. The finance minister of Ghana, K. A. Gbedemah, visited the United States in September-October 1957 - in the midst of the Little Rock crisis. Gbedemah had gone to the United States for meetings at the World Bank and the International Monetary Fund and to lead the Ghanaian delegation to the United Nations. He had also scheduled meetings with American officials to discuss American assistance to Ghana. On the way to Maryland Sate College to deliver an address, in the company of three black American students, one of whom had lived and operated a school in Ghana, Gbedemah was refused sit-down service at a restaurant in Dover, Delaware. When the story was revealed in the press, Eisenhower invited Gbedemah to the White House for breakfast with himself and Vice President Nixon. The American ambassador in Ghana also made a public statement deploring the incident. ${ }^{79}$ Eisenhower's gesture helped to defuse the situation, but the entire incident symbolized the linkage between American race relations and foreign policy. The foreign policy implications of the incident were of considerable importance since the United

77. Lodge to the president, 15 October 1957, FRUS, 1955-1957 (Washington, 1988), II:245-46. In September, Eisenhower had written to Lodge indicating, "I realize, with you, the harm that our prestige has suffered, and if you have any ideas as to how we might try to repair the damage, after the situation calms down, I would be most interested." Eisenhower to Lodge, 27 September 1957, Eisenhower Papers, Ann Whitman File, Administration Series, box 24.

78. Lodge to the president, 15 October 1957, FRUS, $1955-1957$ II:245-46. The reference to the Soviet satellites was the successful launching of Sputnik, which would provoke serious questions in the United States about its technological lead over the Soviet Union. For a discussion of the impact of the Sputnik upon American politics see Robert A. Divine, The Sputnik Challenge: Eisenhower's Response to the Soviet Satellite (New York, 1993).

79. Department of State tel. to the embassy in Ghana, 9 October 1957; and embassy in Ghana tel. to the Department of State, io October 1957, FRUS, 1955-1957 18:378-80. 


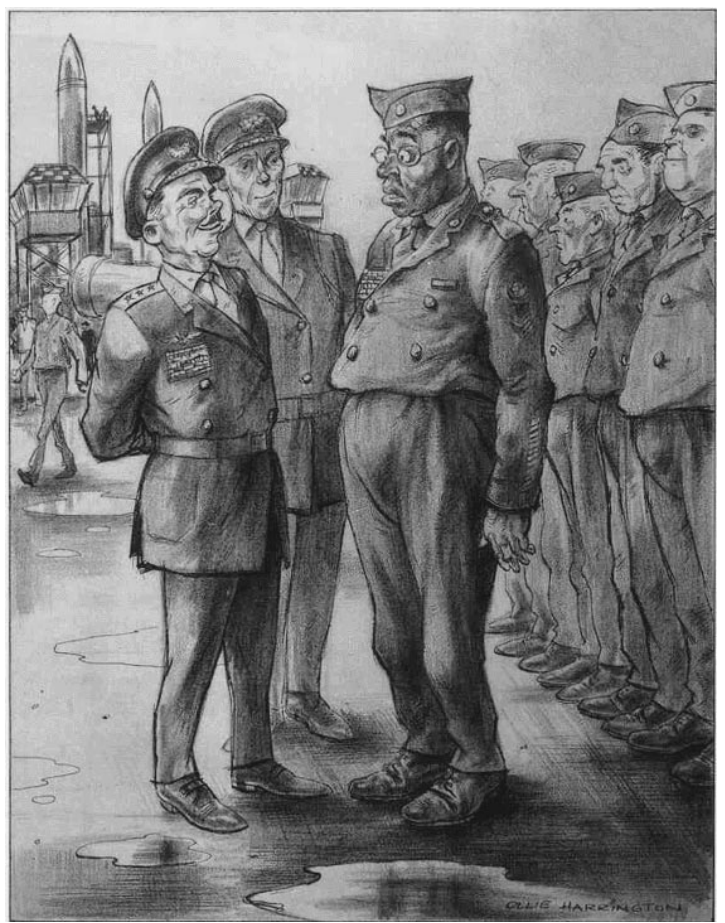

"Congratulations Sergeant Smith. You're to be the first man shot to the moon. It's sort of a goodwill gesture to our African friends!"

Cartoon by Ollie Harrington. Permission: The BALTIMORE AFRO-AMERICAN NEWSPAPER.

States had been attempting to forestall the establishment of diplomatic relations between Ghana and the major Communist states, the Soviet Union and the People's Republic of China. ${ }^{80}$ The incident had also occurred after Nixon's visit to Africa, including his participation in the independence celebrations in Ghana, out of which had come his suggestion that American foreign and domestic policies had to be consistent on the issue of race. For the administration, the year 1957 served as a watershed. Little Rock had forced a departure from the studied indifference to foreign perceptions of American race relations that had shaped the administration's response to the Autherine Lucy case in Alabama.

The transition from colonial rule had begun in Africa, and the administration was clearly sensitive to its implications for both domestic politics and foreign policy. In May 1958, the chairman of the Council on Foreign Economic Policy, Clarence Randall, presented an oral report of his trip to Africa in March

8o. There is extensive documentation on the U.S. effort to disrupt Soviet and Chinese efforts to establish relations with Ghana and Liberia in FRUS, 1955-1957 18:36I-4I4. 
and April at a meeting of the National Security Council. Eisenhower commended Randall's written report to the members of the NSC and described it as "interesting, intriguing, and valuable." Randall described his visit to Africa as "a very stirring adventure" and emphasized that economic and political concerns should outweigh military considerations in shaping American policy toward the sub-Saharan region. He argued that the rise of nationalism was sweeping Central Africa and that the demand for political independence was somewhat "terrifying, as one deduced from reading the biography of Nkrumah." ${ }^{81}$ After a discussion of the records of the various colonial powers in the continent, Randall pointed to the dilemma that had become increasingly tortuous for American foreign policy - the United States was caught between its professions of support for an end to colonialism and the demand by its European partners that it refrain from providing assistance to their African colonies. ${ }^{82}$ Even as he emphasized the growing importance of the African nationalist challenge to European colonial rule, Randall, in response to the prompting of General Robert Cutler, acknowledged that the situation in Liberia was of some concern. He prefaced his remarks on Liberia with the admonition that: "this was a very sensitive situation, discussion of which should be kept within the walls of this room. ${ }^{{ }^{83}} \mathrm{He}$ reported that American companies in Liberia were practicing segregation and had not treated African workers well. As a consequence, the Liberian government had passed an anti-segregation law as an indication of its discontent with the policies of the American companies that Morrow termed "undemocratic and almost uncivilized." ${ }^{4} 4$ Unlike Suez, Liberia made it difficult for the American government to assume the high ground in an effort to distance the United States from its colonial partners. In fact, the situation in Liberia reflected the successful export of American ideas

8r. According to Morrow, who attended the meeting, "Randall came back to this country with a shocked reaction to the treatment of Africans receive from the various nations still holding spheres of influence on that continent." Morrow, Black Man in the White House, 153. The similarities between conditions in parts of the United States for African Americans and conditions under European colonial rule for Africans apparently did not emerge in the discussion, according to the official record of the meeting. See memorandum of discussion at the 365 th meeting of the National Security Council, 8 May 1958, FRUS, 1958-1960 (Washington, 1992), I4:13-16. For a remarkably graphic autobiographical account of growing up black in the American South see Richard Wright, "The Ethics of Living Jim Crow," in Fustice Denied: The Black Man in White America, ed.William M. Chace and Peter Collier (New York, 1970), 270-8I.

82. Memorandum of discussion at the 365 th meeting of the National Security Council, 8 May 1958, FRUS, 1958-1960 I4:13-16. According to Randall, "The metropoles do not want the United States to provide any assistance to their African colonies. On the other hand, the newly independent states insist on knowing where the United States stands on the problem of colonialism. So we are caught on the horns of the dilemma of NATO on the one hand and of a free, non-Communist Africa on the other. Mr. Randall felt the time was approaching when we would have to take a firm stand against colonialism."

83. Ibid. With further prompting from General Cutler, Randall revealed that the issue of discrimination in Liberia also encompassed relations among the descendants of the former American slaves who had settled in that country and who discriminated against the indigenous groups there.

84. Morrow, Black Man in the White House, 154. 
on race that had defined American life since the late nineteenth century. Randall's concerns about the wider dissemination of the information in his briefing was indicative of the sense of siege that was overtaking the administration on the issue of race as a liability for American foreign policy.

The predicament that the American record on race posed for foreign policy was subsequently confirmed by a memorandum, "Treatment of Minorities in the United States - Impact on Our Foreign Relations," prepared by the Civil Rights Commission at the request of the White House. In its summary review, the memorandum acknowledged that racial discrimination had undermined the moral authority of the United States and provided ammunition for the anti-American propaganda disseminated by the Communist states. The memorandum also argued that the "adoption by the Accra Conference of Independent African States in April 1958 of a resolution condemning racial discrimination and segregation is typical of the continuing concern with this question of the nations of Africa and Asia." ${ }^{185}$ The questioning of the moral authority of the American government also came from white-controlled governments in Africa since American racial policies seemed to offer no substantial improvement upon their own records.

One example of the latter sentiment was reported by the American consul in Salisbury who cited a feature article in the Rhodesia Herald of 8 September 1958. The special correspondent who authored the article provided a favorable assessment of Rhodesia's handling of racial problems as compared with the United States and claimed that a Negro would receive a fairer trial in Rhodesia than in any state in the American South. ${ }^{86}$ It was an indication of the American record on race in the late 195 os that white colonists in Southern Rhodesia could lay claim to a more impartial judicial system. The special correspondent for the Rhodesia Herald had touched upon a very sensitive nerve - the treatment of blacks by the judicial system in the South. In August 1958, an Alabama court sentenced Jimmy Wilson, a black man, to death for stealing \$I.95 from a white woman. The death sentence created adverse reaction to the American justice system. In a telegram to Governor James Folsom of Alabama, Dulles indicated that the Department of State and its missions abroad had received considerable correspondence protesting the death sentence. In addition to 650 letters and telegrams, the embassy in London had received a petition for clemency signed by 2,800 people. In Africa, "Prime Minister Kwame Nkrumah has inquired urgently as to the facts in the case and our embassy in Liberia has reported that the execution of Wilson would greatly damage the position of the United States in all of West Africa. ${ }^{187}$ Dulles abjured any effort to influence the case or the governor's handling of the matter. Folsom reported, however, that he was

85. John A. Calhoun (Civil Rights Commission) memorandum to Gerald D. Morgan (White House), 3I December 1958, RG 59, 8II.4II/12-458.

86. Strong despatch to the Department of State, 3 October 1958, RG 59, 8II.4II/IO-358.

87. Dulles tel. to Folsom, 4 September 1958, RG 59, 8II.4II/9-458. 


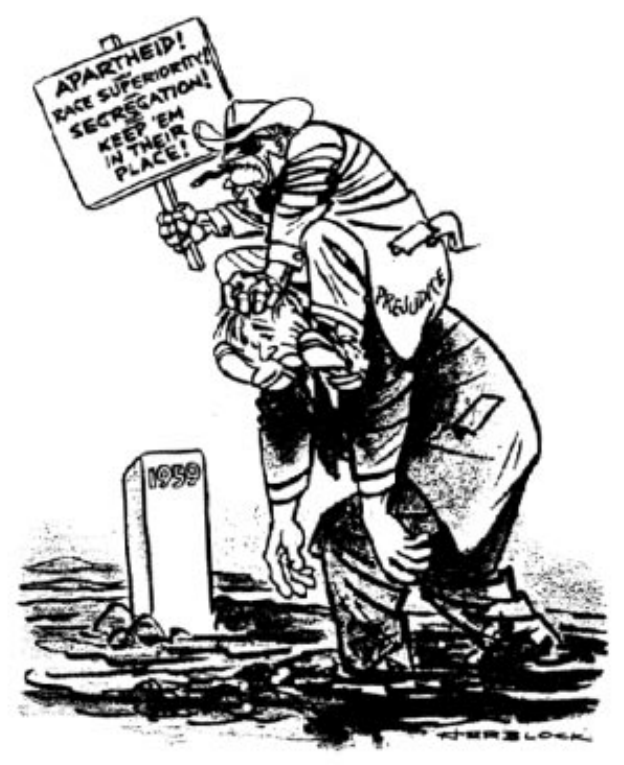

THE WHITE MAN'S BURDEN

THE WHITE MAN'S BURDEN. From: Straight Herblock (Simon \& Shuster, 1964).

receiving up to one thousand letters per day, with some petitions containing four thousand signatures, from countries throughout the world. He indicated that after the judicial appeals process had been fully exhausted, the records would them be submitted to his office for review and a clemency hearing. ${ }^{88} \mathrm{On}$ 29 September, Folsom informed Dulles that he had commuted Wilson's death sentence to life imprisonment. ${ }^{89}$ Dulles's correspondence with Folsom on the Jimmy Wilson case reflected the Eisenhower administration's emerging postI957 strategy of redressing the problems of American race relations as soon as they became an influence upon foreign views of the United States. It was also evidence of the increasing sensitivity of American leaders, even in the South, to international public opinion and criticism of American racial policies.

This shift in policy was not restricted solely to the domestic aspects of race. In the autumn of $195^{8}$, the United States voted for a UN General Assembly

88. Folsom tel. to Dulles, 5 September 1958, RG 59, 8II.4II/9-558.

89. Folsom tel. to Dulles, 29 September I958, RG 59, 8II.4II/9-2958. Folsom also sent a cable to the British Labour party's secretary general, Morgan Phillips, informing him that the death sentence for Wilson had been commuted. The cable was announced to the Labour party's national conference, where the decision to commute the death sentence was cheered but the decision to impose a life sentence on Wilson was jeered. "Folsom Move Cheered," New York Times, I October 1958. 
Resolution condemning apartheid - a switch from its previous efforts to keep the issue away from debate within the United Nations. In a conversation with the South African foreign minister, Eric Louw, after the vote on the UN resolution, the American ambassador sought to convince the foreign minister that the United States had been instrumental in moderating the original resolution. Despite this assurance, the ambassador reported that the South African attributed the shift in American policy to a hardening of the American position, "partially due at least to our domestic problems on racial issues." The American ambassador attempted to devalue American press reports that stressed the connection between American domestic problems and the American vote in the UN but he conceded that "there might be some connection." Louw, revealing the chagrin that afflicted the white minority regime, responded that his government was wounded by the American decision and that the U.S. decision to support the resolution had "mattered perhaps more than all other votes put together ... in view [of] its predominant position of leadership in [the] Western world." ${ }^{\circ}$ The American decision to vote against apartheid at the United Nations in 1958 was symbolic of the heightened American sensitivity to the politics of race in both domestic and foreign policy. The joint public embrace of white supremacy was no longer a cornerstone of the U.S.-South African relationship, and the conversation between the American ambassador and the South African foreign minister revealed the wrenching emotions that accompanied the separation.

As a consequence, symbolic steps to improve foreign perceptions of American foreign policy on the issue of race became evident in American activities at the United Nations. In 1959, the United States supported the candidacy of the Haitian ambassador, Max Dorsinville, for the presidency of the Trusteeship Council for that year in preference to the candidate from Italy. The State Department viewed Dorsinville as a suitable candidate since it was the turn of a non-administering country to serve as president. Ambassador Dorsinville had displayed "relative moderation and sincere endeavors to find compromises in difficult situations," and his previous experience with UN activities in Francophone Africa had made him an obvious candidate for the job. In addition, if elected, Dorsinville would be "the first person of the Negro race to serve as President of an important UN organ." The Italians subsequently withdrew their candidate, whom the State Department considered an excellent choice for the

90. Embassy in South Africa tel. to the Department of State, 7 November 1958, FRUS, 1958-1960 14:730-32. The ambassador went on to explain that: "For one thing it could hardly be denied that our problems at home had made more people aware of and think about racial problems than in years of the recent past. Also if we felt compelled to uphold a vital principle considered West in East-West struggle for men's minds in our own country to extent of much regretted necessity use troops to enforce courts' decision and integration, we would perhaps be less likely avoid taking a position against segregation and discrimination abroad." The curious phrasing of the ambassador's explanation of the shift in the Eisenhower administration's stance on desegregation is very suggestive of the intellectual dissonance that accompanied the waning of "white supremacy" as the official orthodoxy in American life. 
position in $1960 .^{91}$ The decision to support the Haitian candidate for the presidency of the Trusteeship Council reflected an incremental step in the policy of distancing the United States from its European colonial partners.

Even though the administration shifted ground in its support for colonialism and apartheid in the wake of Little Rock, there continued to be a fundamental ambivalence on the issues of race and white minority rule in the non-European world. On 2r March 1960, the South African police killed 68 people and injured 220 in Sharpeville as a result of the escalating confrontation over apartheid policies enacted by the South African government. The director of the Office of News in the State Department, Lincoln White, issued a statement the following day deploring the killings. White refused to interpret the statement and declined to comment on questions from the press. ${ }^{22}$ It would seem that White's statement had been issued without the approval of Secretary of State Christian Herter. In response to Eisenhower's inquiry about the statement, Herter informed the president that there had been a failure to follow established procedure before the statement had been made to the press. The secretary was furious and saw the statement as a discourtesy to South Africa. Eisenhower advised that the South African government should be informed that "although we are much distressed by events in South Africa, we do not regard it as our business to make public statements about this, and officially regret having done so." The president further indicated that "This action should be kept secret." ${ }^{\prime 3}$ Herter's reaction was based in part on the fact that the standard procedures for the release of statements to the press had not been followed. He was also concerned that "the issuance of a statement of this nature outspokenly critical of a Government with which we maintain friendly relations, and on a subject which bas not only world-wide interest, but also involves domestic political factors - is, it seems to me, a decision to be taken only at the highest level in the Department of State." Herter was also afraid that the United States had "clearly taken sides and might be accused of inciting a revolution." 94 Ironically, the Afro-Asian group at the United Nations had given the statement a warm reception. The group had extended thanks to the United States for it even as they sought an immediate meeting of the UN Security Council to discuss events in South Africa. 95

The reaction in South Africa to the American statement was revealing about the polarization of opinion on the issue of apartheid. The U.S. embassy reported that the South African government was bitterly resentful, a sentiment shared by the "great mass of Afrikaner people, who feel we have sold out Whites to

9I. Deputy assistant secretary of state for international organization affairs (Henderson) to the undersecretary of state (Herter), I6 January 1959, FRUS, I95 8-1960 (Washington, 1990), 2:94-96. 92. Editorial note, ibid. $14: 74 \mathrm{I}-42$. The editorial note contains only excerpts of memoranda dealing with the issue.

93. Ibid.

94. Ibid.

95. Ibid. (emphasis added). 


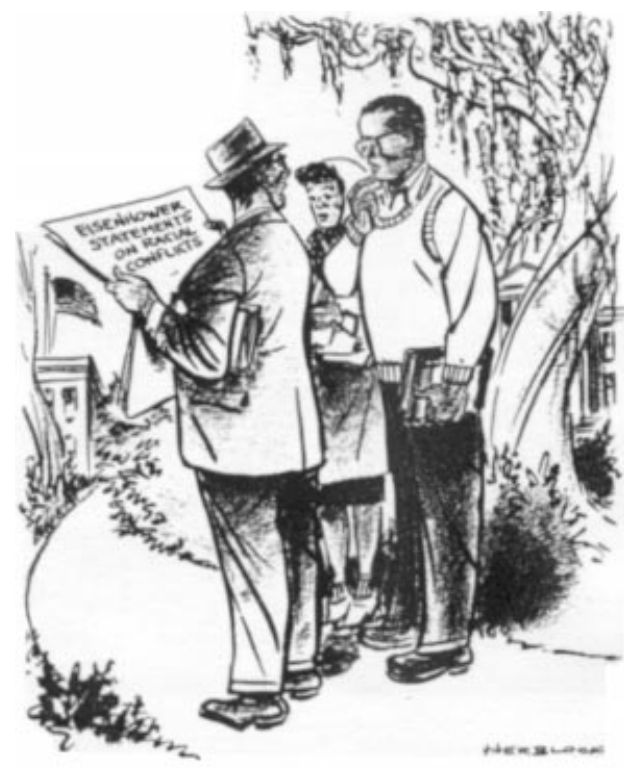

\section{"YOU THINK HE MIGHT GET INTERESTED IN US IF WE MOVED TO SOUTH AFRICA?"}

"YOU THINK HE MIGHT GET INTERESTED IN US IF WE MOVED TO SOUTH AFRICA?". From: Straight Herblock (Simon \& Shuster, 1964).

curry favor with Blacks." While the embassy sensed that relations between the two governments had not been permanently damaged, it was clear that the South African government was feeling increasingly besieged by the apparent loss of American endorsement of its racial policies. On the other hand, the embassy also reported that the conservative opposition, while regretful of American commentary on the internal affairs of South Africa, agreed that the "civilized world [was] horrified at [the] situation, by Nationalist race policies." Further, the liberal opposition endorsed the statement, while non-White groups were "delighted [with] our statement and belief spreading that US now supports their course." The embassy also reported that the government was planning to ban the African National Congress and the Pan-Africanists and there was a tense atmosphere "to which our statement [on] this contributed." The embassy closed its despatch with a reminder that the foreign minister, Eric Louw, had been informed that "there is no change in US policy toward his country." ${ }^{6}$ On the other hand, there was no public retraction of the statement issued by the State Department without the secretary's approval.

96. Embassy in South Africa tel. to the Department of State, 25 March 1960, ibid., 743-44. In June 1960, however, the United States decided to admit Oliver Tambo of the African National 
The conflicting signals coming from the State Department, the supportive response of white and colored South Africans, the welcome given by the Afro-Asian group at the United Nations to the American statement, and the dismay of the Afrikaner regime were evidence of the multiple pressures upon American policy. In this context, the president's actions were revealing about the struggle to shape American foreign policy in the non-European world after Little Rock. The strength of Eisenhower's personal support for the South African government became clear in Anglo-American discussions on the South African issue before the UN Security Council. President Eisenhower hosted a meeting with a British delegation led by Prime Minister Harold Macmillan at Camp David. Macmillan sought American support to ensure that the UN Security Council statement coming out of the meeting would be innocuous and hoped that the American representative, Henry Cabot Lodge, in his role as chair of the council would facilitate that process. Eisenhower agreed to the strategy advanced by Macmillan. ${ }^{97}$ The president's stance reflected, as did the decision to send troops to Little Rock, his personal ambivalence about the widening challenge to the politics of white supremacy and the linkages in his views of the racial problems in South Africa and the United States..$^{98}$

Eisenhower's anxiety about the pace of change in the non-European world was not restricted to South Africa. In December 1960, after considerable debate, the UN General Assembly voted on a resolution on colonialism sponsored by forty-three countries on the initiative of the Afro-Asian group in the UN. Despite reservations about the text, the US Mission to the United Nations and the State Department had decided to vote for the resolution. It was a decision with which Eisenhower initially concurred, though he expressed serious reservations about the document. But upon receipt of a letter from British Prime Minister Macmillan expressing his shock that the United States was prepared

Congress, an act considered "unfriendly" by the South African government. See Embassy in South Africa tel. to the Department of State, 30 June 1960, ibid., 752-53.

97. Memorandum of conversation, 28 March 1960, ibid., 745-47. The president "said that he would agree with such a procedure. He had strong feelings that one could not sit in judgment on a difficult social and political problem six thousand miles away. He had to say that our own problem was in his mind in this connection, and that he had some sympathy even with his friends in Atlanta on some of their difficulties. He suggested that a UN resolution could perhaps just express regret about the disturbances in South Africa and hope that measures would be taken to prevent their recurrence."

98. Even though Eisenhower's reactions betrayed his personal predilection for siding with the white-minority government in South Africa, it had become evident since Little Rock that the United States would publicly continue to dissociate itself in the United Nations from the apartheid policies in South Africa. The South African foreign minister was informed at a meeting in the Department of State with Secretary Herter, in response to the foreign minister's reiteration of his government's unhappiness with the statement on the Sharpeville incident and U.S. votes in the United Nations against South Africa's racial policy, that the United States hoped "real progress can be made in ameliorating racial conditions in the Union. While we have always fully appreciated the difficulties of the problem, we cannot support South Africa's official racial policy." Memorandum of conversation, 25 October 1960, ibid., 757-60. 
to support the resolution and asking the United States to join Britain in abstaining on the vote, Eisenhower reversed himself and instructed the State Department to abstain. In addition, he requested the State Department to approach certain African delegations at the UN with a view to persuading them to abstain on the resolution. ${ }^{99}$ That request was a measure of Eisenhower's hubris on the issue of colonialism.

It was a decision that was not easily accepted by the American delegation to the United Nations General Assembly. American Ambassador James Wadsworth at the United Nations stated for the record and personally to Herter that he was "shocked and disheartened" bythe decision to abstain. ${ }^{100}$ Wadsworth believed that since the United States had already informed its Asian allies, the Philippines and Japan, of its decision to back the resolution, any change would be interpreted as evidence of American support for its colonial partners. ${ }^{\text {Ior }} \mathrm{A}$ black member of the American delegation to the United Nations, the sociologist and opera singer Zelma Watson George, stood and applauded the adoption of the resolution by the General Assembly and later said that she was of the view that "no one in the delegation supported the abstention." Her action caused a stir among the delegates but she indicated that she felt an obligation to show her opposition to the American abstention and was glad that she had acted in accord with her feelings. ${ }^{102}$ The willingness of the American representatives at the UN to signal their disapproval of the decision taken by Eisenhower revealed the gap between the president and others involved in shaping American foreign policy. Eisenhower's hubris appeared to flow from his failure to acknowledge that American aspirations for leadership in the international arena required the ability to fashion effective coalitions with other states. On the issues of South Africa and colonialism, Eisenhower betrayed his lack of contact with the shifting climate of international and domestic opinion. ${ }^{103}$

99. Editorial note, ibid. 2:457-58.

Ioo. Mission at the United Nations tel. to the Department of State, I4 December 196o, ibid., 459. The final vote was 89 to o, with the United States joining Australia, Belgium, Britain, the Dominican Republic, France, Portugal, Spain, and South Africa in abstaining. Only the Dominican Republic was not a colonial power and it was the only Latin American state that did not support the resolution.

IoI. Ibid. Wadsworth emphasized that: "It is also particularly unfortunate this last minute reversal was made after Department informed Tokyo and Manila we would support this resolution; it seems inescapable that word will spread that our vote on this issue, of critical importance to Asians and Africans, was determined by wishes of colonial powers which even we recognize as such."

102. The New York Times, 15 December 1960. The newspaper reported that "Mrs. George's action reminded delegates of a similar move made two years ago by Marian Anderson, another noted Negro, while serving with the United States delegation. After voting against a motion to call a special session of the Assembly to study the Cameroons, Miss Anderson made it clear that she was "a member of an instructed delegation, and we are here to carry out what is wanted."

I03. The irony of Eisenhower's instruction for the United States to abstain on the vote was that it followed upon an apology issued by Eisenhower himself to Michel Gallin-Douathe, the Central African Republic representative to the UN, for an incident in Baltimore where he was refused service in a restaurant. Gallin-Douathe had gone to Washington to present his credentials to 


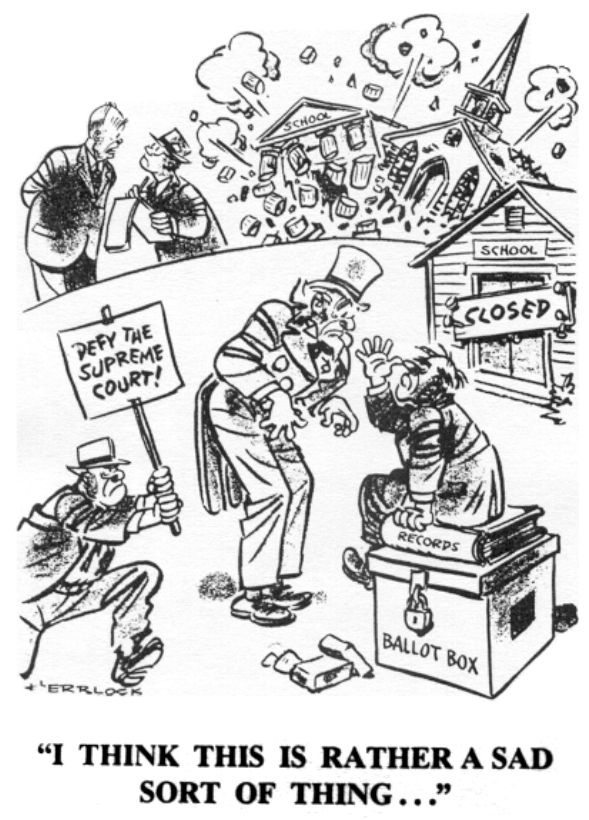

"I THINK THIS IS A RATHER SAD SORT OF THING". From: Straight Herblock (Simon \& Shuster, 1964).

The divergences within the administration over the Sharpeville crisis and the UN resolution on colonialism underscored the state of flux that had overcome American policy. ${ }^{104}$ Prior to the Little Rock episode, the Eisenhower administration had assumed that it could afford to ignore international critiques of American race relations and even help South Africa to insulate itself from international condemnation of its apartheid policies. The sanguine dismissal of international opinion proved to be of limited duration, as the Little Rock crisis shattered the notion that America was immune to criticism. Debates

Eisenhower and was on his way back to New York when the incident occurred. The United States Mission to the United Nations recommended that there should be an apology from the president. It reported that the story was circulating among the representatives of the African countries, and that the Guineans and Ghanaians were "making [a] special point in conversations with African colleagues of citing this case as proof [that] America is a nation of racists." The mission saw the presidential apology as a way of defusing the potential problems for American relations with the African states raised by the incident. Eisenhower sent an apology deploring the incident and assuring Gallin-Douathe that the United States would continue its efforts to eliminate the causes of such incidents. The letter concluded: "The United States attaches great importance to the friendship of the African people. I hope you will judge this regrettable incident, which reflects the attitude of only a minority of the citizens of this country, in its proper perspective." Editorial note, which contains excerpts of the documents pertaining to the issue, FRUS, 1958-1960 2:438-39.

I04. Michael Krenn has shown the ways in which even the administration's propaganda efforts fell victim to that state of flux. See Michael L. Krenn, "Segregation and the 1958 World's Fair," Diplomatic History 20 (Fall 1996): 59I-6I2. 
within the administration about race and colonialism after Little Rock reflected a sense of siege in dealing with the manifest volatility of the challenge to the notion of white/European supremacy. There was a growing realization that America was as much part of the problem as its European partners and that its leadership role would be seriously compromised if it did not become part of the solution. Unfortunately, the Eisenhower administration proved to be unable to mount the necessary effort to devise a legitimate solution to the problems of race within the United States and internationally. The ambivalence that Eisenhower betrayed on issues of race in foreign policy paralleled his handling of the Little Rock crisis - he was profoundly uneasy about acknowledging the legitimacy of claims of people of color when faced by intransigent whites. ${ }^{105}$ Even as he was willing to make an effort to redress wrongs inflicted upon individual African diplomatic representatives by Americans, he seemed unable to understand the broader challenge to colonialism and apartheid by people of color. His role in shaping the American response to these issues revealed the extent to which his personal influence helped to define American foreign policy. Nonetheless, international scrutiny and criticism of American society had created a climate in which Eisenhower appeared increasingly to be an anachronism. ${ }^{106}$ The changed international context opened the way for the emergence of the Kennedy administration with its promise of a new beginning in American policy toward European colonialism and the domestic politics of race.

I05. A vivid example of this tendency was exemplified by Eisenhower's resistance to appeals to intervene, even if symbolically, in the situation in New Orleans in November 1960 where white protesters had mounted a vigorous campaign against the desegregation of the schools. Ward Melville, who had served as a trustee of Columbia University when Eisenhower was president of that institution, sent a note to the president in November 1960 suggesting that Eisenhower should speak out on "this New Orleans integration matter." He attached a letter to the editor of the New York Times that argued "how fitting it would be for the President, by deed or word, to pay tribute to these Negro kids, their parents, friends and counterparts who unquestionably represent the highest expression of the spirit, the courage, the moral dedication that have taken America so far. As a lame-duck President there are no votes to win or lose; there is no one to impugn his motive. All that is necessary is the belief and the desire." Ward Melville to Eisenhower, I9 November 1960, Eisenhower Papers, Central Files, OF I42-A-5-A, box 733. Eisenhower sent a non-committal response that "any statement or action respecting this delicate situation must be very carefully weighed both as to content and timing. I appreciate your feeling and, of course, will stay in continuous close touch with the developing situation." Eisenhower to Melville, 30 November 1960, Eisenhower Papers, Central Files, OF I42-A-5-A, box 733. A similar appeal from Senator Jacob Javits of New York received an equally non-committal response. Eisenhower Papers, Central Files, OF I42-A-5-A, box 733 .

Io6. As Robert MacMahon has argued, it is not possible to provide a thorough evaluation of Eisenhower as a president without assessing his policy toward the rise of non-European nationalism. I would only add that non-European nationalism and civil rights are two sides of the same coin when such an assessment is contemplated. See Robert J. MacMahon, "Eisenhower and Third World Nationalism: A Critique of the Revisionists," Political Science Quarterly ror, no. 3 (1986): 453-73. 